\title{
Differential analysis of five quinoa (Chenopodium quinoa $W$.) genotypes under different salt stresses in a controlled environment
}

\author{
Asad Sarwar Qureshi ${ }^{1}$, Ashenafi Worku Daba² \\ ${ }^{1}$ International Center for Biosaline Agriculture (ICBA), P.O. Box. 14660 Dubai, UAE. \\ ${ }^{2}$ Soil Scientist, Ethiopian Institute of Agricultural Research (EIAR), Ethiopia.
}

Received date: 12 December 2019, Accepted date: 28 February 2020, Online date: 1 April 2020

\author{
Address for Correspondence: \\ Asad Sarwar Qureshi, Senior Scientist, International Center for Biosaline Agriculture (ICBA), P.O. Box. 14660, Dubai, UAE. \\ Email: a.qureshi@biosaline.org.ae
}

Copyright (C 2020 by authors and American-Eurasian Network for Scientific Information.

This work is licensed under the Creative Commons Attribution International License (CC BY).

http://creativecommons.org/licenses/by/4.0/

\section{(c) (i) Open Access}

\begin{abstract}
Soil salinization is a global problem which restricts the choice of crops for cultivation. Management and reclamation of saline soils using costly and time-consuming methods such as the installation of drainage systems are beyond the reach of poor farmers. Therefore, it is crucial to look for alternate crops which are more salt-tolerant. One such crop is quinoa (Chenopodium quinoa $\mathbf{W}$.), which has high nutritious value and capacity to grow in marginal conditions. As crops vary in their tolerance to salinity, they need to be evaluated for different salinity conditions. This study was conducted to evaluate five quinoa genotypes (ICBA-Q1, ICBA-Q2), ICBA-Q3, ICBA-Q4 and ICBA-Q5) for their salinity tolerance under four artificially induced salinity $\left(5,10,15,20 \mathrm{dS} \mathrm{m}^{-1}\right)$ levels. The parameters studied were the rate of seed germination, plant height, dry biomass, nutritional content and grain yield. The results indicate that salinity had an inhibitory effect on all parameters. Out of 5 quinoa genotypes, ICBA-Q3 and ICBA-Q4 proved more salt-tolerant under saline conditions concerning dry biomass and grain yield and nutritional contents. Therefore these two genotypes are recommended to farmers for large-scale adaptation in the salt-affected areas of Ethiopia.
\end{abstract}

KEYWORDS

grain yield, soil salinity, Ethiopia, biomass yield, nutritional contents

\section{INTRODUCTION}

Ethiopia has an estimated 11 million ha of land exposed to salinity, which is equivalent to $13 \%$ of the total irrigated area of the country [1,2]. These soils are mainly located in the Rift Valley, Wabi Shebelle River Basin, the Denakil Plains and other lowlands of the country, which is home to $10 \%$ of the total population [3]. The increasing prevalence of these soils has reduced the production potential of soils, which is directly affecting the food security and livelihood of the rural communities in the country. Due to the increasing demand for food, farmers are making attempts to increase the irrigated area to increase agricultural productivity. However, this has been done without the provision of the active drainage network. Under these conditions, the problems of soil salinity are likely to increase in future. Therefore, it is crucial to develop an integrated strategy for the reclamation of saline soils to boost agricultural production to ensure future food security [3].

In the Rift and lower Awash valley agricultural system of Ethiopia, development of large irrigation schemes without effective drainage systems and poor irrigation management practices have resulted in the rapid rise of saline groundwater. Due to high temperatures, water evaporates from the soil surface, leaving the salt behind, 

quinoa $W_{\text {.) }}$ genotypes under different salt stresses in a controlled environment/American-Eurasian Journal of Sustainable Agriculture. 14(1): 14-21.DOI: 10.22587/aejsa.2020.14.1.2

causing secondary salinization [2]. It is generally believed that in a business as usual scenario, salinity problems will further exacerbate with serious concerns about the food security of the country.

For future food security of the country, reclamation of existing saline soils and prevention of other areas from salinity development is of principal importance. For this purpose, there is a need to develop an integrated approach considering the salinity status of soils in different regions. The areas with low to moderate salinity, reclamation can be achieved through effective leaching of salts and proper management of soil and water resources. The highly saline soils can only be reclaimed by the use of chemical amendments and installation of adequate drainage systems. However, these strategies are costly, time-consuming and difficult to implement by farmers due to lack of financial and technical resources. These soils can be reclaimed by the adoption of biosaline approach. This approach involves the introduction of salt-tolerant food and forage crops. These integrated food and forage systems can help smallholder farmers to diversify their cropping systems to feed their families and livestock. For this purpose, the selection of diverse food and forage species with the capacity to tolerate salt and water stress is of vital importance.

Quinoa (Chenopodium quinoa Willd) has emerged as an ideal crop for drought-prone and salinized agricultural areas due to its high nutritious value and ability to grow in marginal conditions $[4,5,6]$. Quinoa has long been grown in the Andes region. However, it is farming in other regions is still in experimental phase [7]. Quinoa can be grown from non-saline to highly saline soils where other plants either fail to grow or grow very poorly [8]. Quinoa is gluten-free and rich in proteins and essential amino acids such as lysine, threonine and methionine. It also has high contents of much needed unsaturated fatty acids (i.e. linoleic, oleic and linolenic), of minerals $(\mathrm{Ca}$, $\mathrm{Fe}, \mathrm{Cu}, \mathrm{Zn}$ ) and vitamins (A, B2, C and E) [9]. In addition, quinoa is a good source of vitamins, oil (high in omega 3, linoleic and linolenic acids, 55-66\% of the lipid fraction), and natural antioxidants such as a and $\mathrm{g}$ tocopherol, and it has more minerals such as $\mathrm{Ca}, \mathrm{Fe}, \mathrm{K}, \mathrm{Mg}, \mathrm{Cu}$, and $\mathrm{Mn}$ than other cereals [19]. Quinoa is suitable for lactose-tolerant consumers and those allergic to gluten. It can also be used as a highly nutritious feed for animals.

Quinoa is heat sensitive and can sustain temperatures up to $35^{\circ} \mathrm{C}$. Above this temperature, plant dormancy or pollen sterility may occur [10]. The quinoa may encounter poor seed germination and crop establishment problems in salt-affected areas [6]. The yield differences are enormous, ranging from 0.6 to 3.9 tha $^{-1}$ depending on soil, water and climatic conditions [10]. This clearly indicates the need for further research to develop varieties that can produce consistent yields under different agro-climatic conditions. In this study, the response of five quinoa genotypes to 5 salinity levels (control, $5,10,15$ and $20 \mathrm{dS} \mathrm{m}^{-1}$ ) is evaluated for the Afar region of Ethiopia. The outcome of this study is expected to help farmers in the selection of appropriate quinoa varieties for saline areas in different parts of Ethiopia and other countries of the region having similar agro-climatic conditions.

\section{Study area}

\section{MATERIALS AND METHODS}

The experiments were conducted at the Werer Agricultural Research Center (WARC), Amibara, Ethiopia, which is located at $278 \mathrm{~km}$ to the east of Addis Ababa. The area is relatively flat with slope gradients of 1-2\% (Fig. 1). The mean annual rainfall is $570 \mathrm{~mm}$ with a minimum and maximum temperatures of $19^{\circ} \mathrm{C}$ and $34^{\circ} \mathrm{C}$, respectively. Higher soil evaporation due to extreme temperatures causes the creation of saline soils and nutrient disparity in the soils causing weak plant growth. The Vertisols soil type of the area varies from silty clay to clay, whereas the texture of the Fluvisols soils sandy loam to silty loam [11]. 
Fig. 1: Location map of the study area.

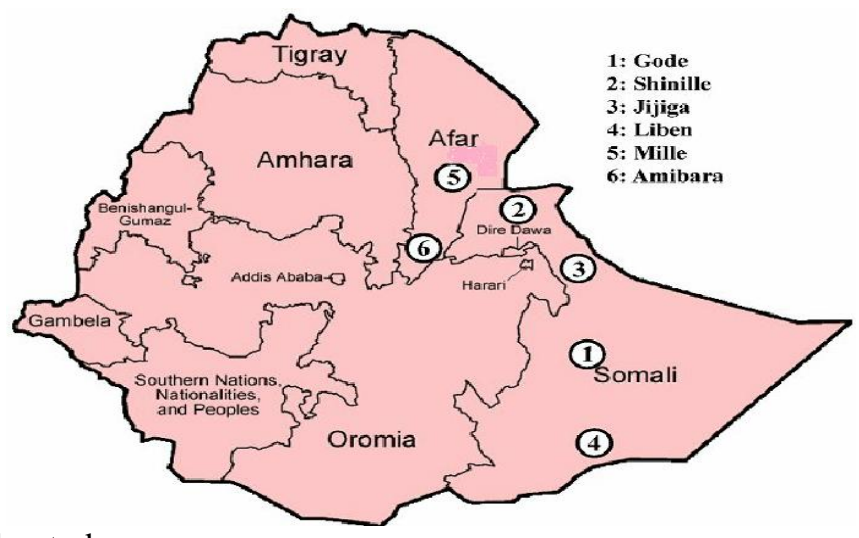

\section{Observations and measurements}

For pot trials under controlled conditions, four salt stress treatments were prepared by mixing 7.3 14.6, 21.4 and $29.1 \mathrm{~g}$ of $\mathrm{NaCl}$ into $6.0 \mathrm{~kg}$ of soil packed per pot to produce salinity levels of 5, 10, 15 and $20 \mathrm{dS} \mathrm{m}^{-1}$. Five quinoa genotypes (ICBA-Q1, ICBA-Q2, ICBA-Q3, ICBA-Q4, ICBA-Q5) taken from the International Center for Biosaline Agriculture (ICBA) were evaluated to test their performance under different soil salinity conditions. The treatments were organized in a completely randomized design with three replications.

Ten seeds of each genotype were sown in each pot. The seeds were surface sterilized using $70 \%$ ethanol (exposure for $10 \mathrm{sec}$ ) followed by immersion for 10 minutes in sodium hypochlorite solution $(\mathrm{NaOCl} ; 5 \%$ active chlorine). The treated seeds were washed thoroughly with distilled water and were placed on moist filter paper in Petri dishes. Uniformity of seed size and quality was ensured before germination test. Since soils of the study area are good in nutrients, no fertilizer was used for these experiments. Irrigations were done with fresh canal water $\left(E C=0.3 \mathrm{dS} \mathrm{m}^{-1}\right)$.

Irrigations were applied according to crop evapotranspiration $\left(\mathrm{ET}_{\mathrm{c}}=\mathrm{ET}_{\mathrm{o}} \mathrm{x} \mathrm{K}_{\mathrm{c}}\right.$ ), which was calculated by multiplying reference evapotranspiration $\left(\mathrm{ET}_{\mathrm{o}}\right)$ with the crop coefficient $(\mathrm{Kc})$. The reference evapotranspiration $\left(E_{0}\right)$ was calculated using a modified Penman-Monteith equation, whereas the Kc values were taken from FAO-56 publication. In addition to total irrigation requirements $\left(\mathrm{ET}_{\mathrm{c}}\right)$, an additional $10 \%$ of the total irrigation amount was applied to leach down salts from the root zone. Mean germination time (MGT), germination percentage (GP), plant height, biomass and grain yields, shoot and root dry matter yields and other related data was measured. Dry biomass yield was attained by oven-drying fresh biomass at $65^{\circ} \mathrm{C}$ to constant weight. Seeds with full radicle were considered as germinated. Germination count was done on $5^{\text {th }}, 10^{\text {th }}$ and $15^{\text {th }}$ day after plantation. GP was calculated according to [12] whereas MGT was determined using the equation of [13].

$G P=\frac{\text { Total germinated seeds }}{\text { Total number of seeds }}$

$M G T=\frac{\sum D n}{\sum n}$

Where

$n=$ Number of germinated seeds on day $\mathrm{D}$, and

$D=$ Number of days from the start of germination.

Chlorophyll content (SPAD units) of leaves was measured using Minolta Soil-Plant-Analysis Development (SPAD) meter. Plant height was measured with a standard ruler (i.e., stem length from soil level to the top of the flower head). The dried and grounded plant samples were used to analyze the nutritional contents of the seeds using standard methods as described in Van Siest et al. [14].

\section{Statistical analysis}

Two-year experiments were conducted (2017-18), and the data were subjected to analysis of variance (ANOVA) technique [15] for factorial CRD using SAS 9.3 software (SAS Institute, Cary, NC). The significance of differences between the mean values at $\mathrm{p}<0.05$ was determined using Least Significance Difference (LCD) test. The comparison between all data obtained was made by using Duncan's Multiple Range Test (DMRT). 
Asad Sarwar Qureshi, Ashenafi Worku Daba., 2020. Differential analysis of five Quinoa (Chenopodium quinoa $W_{\text {.) }}$ genotypes under different salt stresses in a controlled environment/American-Eurasian Journal of Sustainable Agriculture. 14(1): 14-21.DOI: 10.22587/aejsa.2020.14.1.2

\section{RESULTS}

Germination percentage (GP), mean germination time (MGT) and germination index (GI)

For all genotypes, increasing salinity affected seed germination. The GP was highest in ICBA-Q3, ICBA-Q4 and ICBA-Q5 in control and gradually decreased with the increasing salt concentration. The lowest GP was recorded in ICBA-Q1 and ICBA-Q2 genotypes at all salinity levels whereas ICBA-Q4 gave the highest GP at salinity level of $20 \mathrm{dS} \mathrm{m}^{-1}$. Similarly, mean germination time (MGT) increased with growing salinity levels. The highest MGT was recorded in ICBA-Q1 at $20 \mathrm{dS} \mathrm{m}^{-1}$, followed by ICBA-Q2 (Table 1). MGT for all genotypes was comparable up to salinity level of $10 \mathrm{dS} \mathrm{m}^{-1}$. However, at higher salinity levels (15-20 dS m $\mathrm{m}^{-1}$ ), MGT for ICBA-Q3, ICBA-Q4 and ICBA-Q5 were lower than ICBA-Q1 and ICBA-Q2. The lowest MGT was found in ICBA-Q3 in control. GI also followed the trends of GP for all genotypes. The maximum GI was observed in ICBA-Q5 followed by ICBA-Q3 and ICBA-Q4 at control. Lower GI values were observed at the highest salt concentration levels for all genotypes.

Table 1: Effects of salinity on GP, MGT and GI of five quinoa genotypes.

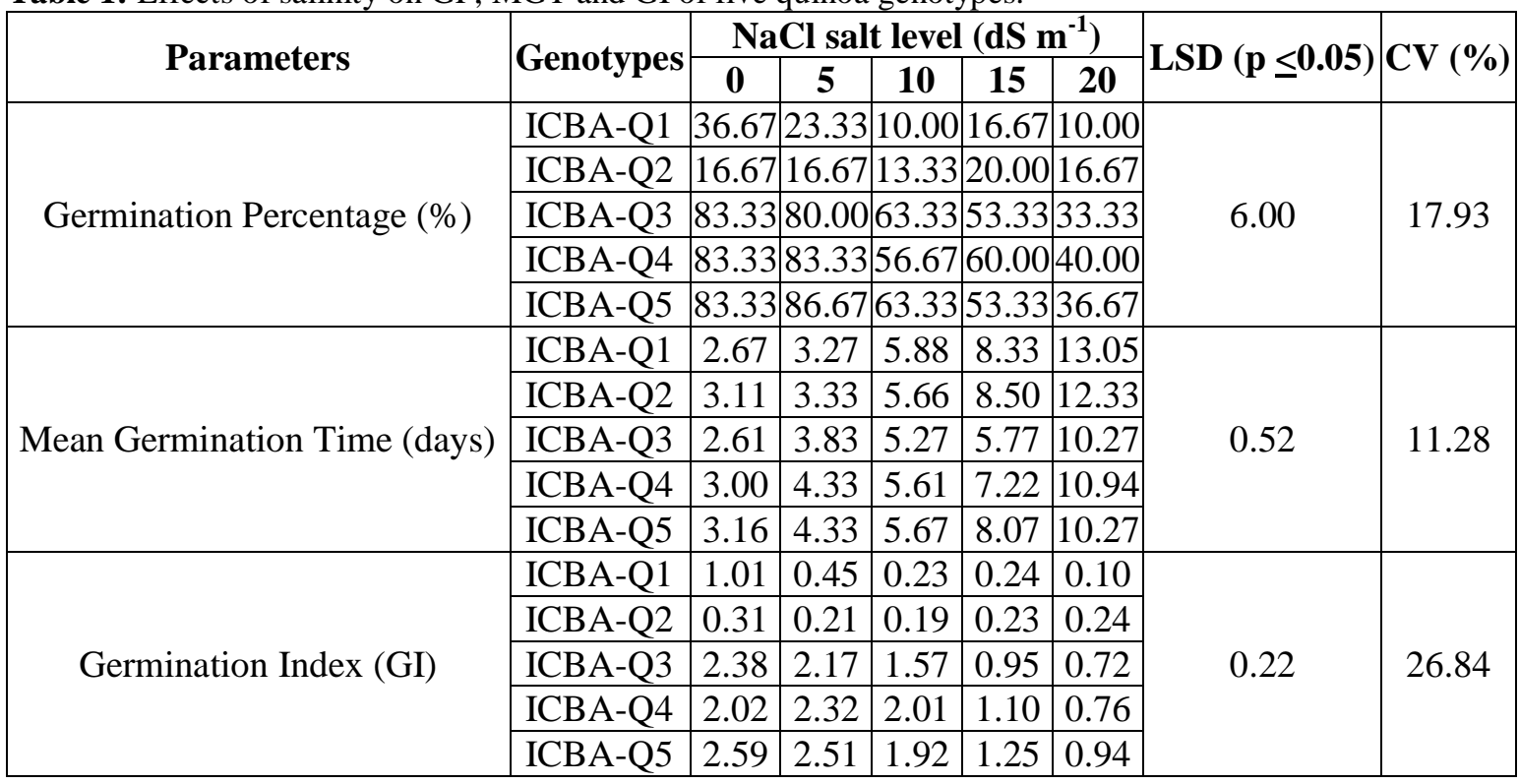

\section{Plant height}

For all quinoa genotypes, a declining trend in plant height was noted with the increasing salinity. The maximum plant height was observed for ICBA-Q3 followed by ICBA-Q4 at $0 \mathrm{dS} \mathrm{m}^{-1}$. However, at higher salinity level (20 $\mathrm{dS} \mathrm{m^{-1 }}$ ), plant height of ICBA-Q3 and ICBA-Q4 was reduced by $41 \%$ and $44 \%$, respectively. Table 2 shows that the plant height of all quinoa genotypes reduced significantly after $10 \mathrm{dS} \mathrm{m}^{-1}$. These results agree with those of Jacobsen [16] and Al-Dakheel et al. [17] who found a significant reduction in plant height with the increasing salinity levels in Phaseolus species and Lentils.

Table 2: Effects of salinity on plant height of five quinoa genotypes.

\begin{tabular}{|c|c|c|c|c|c|c|c|c|}
\hline \multirow{2}{*}{ Parameters } & \multirow{2}{*}{ Genotypes } & \multicolumn{5}{|c|}{ NaCl salt level $\left(\mathrm{dS} \mathrm{m}^{-1}\right)$} & \multirow{2}{*}{ LSD $(p \leq 0.05)$} & \multirow{2}{*}{$\mathrm{CV}(\%)$} \\
\hline & & $\mathbf{0}$ & 5 & 10 & 15 & 20 & & \\
\hline \multirow{5}{*}{ Plant height $(\mathrm{cm})$} & ICBA-Q1 & 68.67 & 67.00 & 67.67 & 61.67 & 42.47 & \multirow{5}{*}{4.01} & \multirow{5}{*}{8.05} \\
\hline & ICBA-Q2 & 68.33 & 67.67 & 67.33 & 63.67 & 45.67 & & \\
\hline & ICBA-Q3 & 92.67 & 84.00 & 74.67 & 63.00 & 54.66 & & \\
\hline & ICBA-Q4 & 92.33 & 85.00 & 69.47 & 59.33 & 51.00 & & \\
\hline & ICBA-Q5 & 70.00 & 65.33 & 60.67 & 56.00 & 48.33 & & \\
\hline
\end{tabular}

\section{Dry biomass yield}

In all quinoa genotypes, dry biomass yield was reduced due to increased salt stress (Fig. 2). The highest dry biomass yield was obtained in ICBA-Q3 at $0-5 \mathrm{dS} \mathrm{m}^{-1}$ whereas the lowest was obtained in ICBA-Q1 and ICBAQ2. ICBA-Q4 performed better at higher salinity levels (15-20 dS m$\left.^{-1}\right)$. The dry biomass yield decreased with 
Asad Sarwar Qureshi, Ashenafi Worku Daba., 2020. Differential analysis of five Quinoa (Chenopodium quinoa $W_{\text {.) }}$ genotypes under different salt stresses in a controlled environment/American-Eurasian Journal of Sustainable Agriculture. 14(1): 14-21.DOI: 10.22587/aejsa.2020.14.1.2

the increasing soil salinity in the growth medium, although the response of all five genotypes to different salinity levels was heterogeneous. At $0 \mathrm{dS} \mathrm{m}^{-1}$, dry biomass yield of ICBA-Q1, ICBA-Q2, ICBA-Q3, ICBA-Q4, and ICBA-Q5 was 15.5, 12.5, 29.6, 25.0 and $21.0 \mathrm{~g} / \mathrm{plant}$, respectively. However, the dry biomass yield at $20 \mathrm{dS}$ $\mathrm{m}^{-1}$ was noted as $5.1,8.6,17.1,18.1$, and $13.5 \mathrm{~g} / \mathrm{plant}$, registering a drop of $67 \%, 30 \%, 42 \%, 28 \%, 36 \%$ for ICBA-Q1, ICBA-Q2, ICBA-Q3, ICBA-Q4, and ICBA-Q5, respectively.

The highest reduction in dry biomass yield per unit increase of salinity $\left(1 \mathrm{dS} \mathrm{m}^{-1}\right)$ was observed in ICBA-Q3 (0.56 g/plant) followed by ICBA-Q1 (0.48 g/plant) and ICBA-Q2 (0.46 g/plant). The lowest reduction in dry biomass per unit of salinity increase was found in ICBA-Q4 (0.38 g/plant) and ICBA-Q5 (0.22 g/plant). These two genotypes showed more stable dry biomass yields under all salinity levels. The dry biomass yield for ICBAQ3 declined significantly after $5 \mathrm{dS} \mathrm{m}^{-1}$, whereas this was not the case for ICBA-Q4 and ICBA-Q5. This suggests that for higher salinity levels $\left(10-20 \mathrm{dS} \mathrm{m} \mathrm{m}^{-1}\right)$, ICBA-Q4 and ICBA-Q5 are more suitable due to their higher salt tolerance capacity.

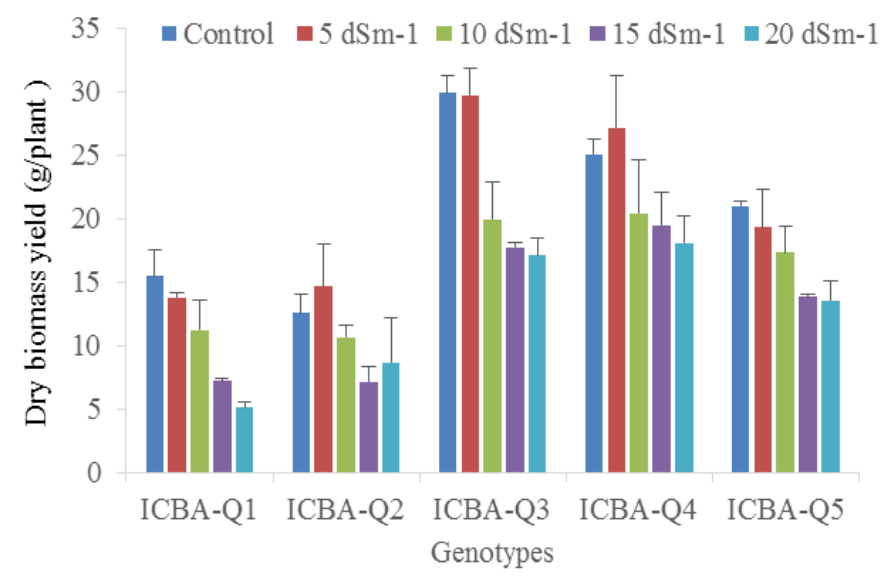

Fig. 2: Dry biomass yield of five quinoa genotypes as affected by different salinity levels.

\section{Grain yield}

The grain yield was also negatively affected by increasing salinity levels (Figure 3); however, the effect was more pronounced at higher salinity levels. ICBA-Q1 and ICBA-Q2 produced the lowest grain yield at all salinity levels, whereas the highest grain yield at all salinity levels was obtained for ICBA-Q3 followed by ICBA-Q4 and ICBA-Q5. The differences in grain yields under ICBA-Q3 and ICBA-Q4 were non-significant. The grain yield of ICBA-Q4 and ICBA-Q5 was $10 \%$ and $42.5 \%$ less than the grain yield of ICBA-Q3 at $0 \mathrm{dS} \mathrm{m}^{-}$ 1 . However, the reductions in grain yields at the higher salinity levels were relatively lower than the control, i.e., grain yield of ICBA-Q4 and ICBA-Q5 was $4.8 \%$ and $38 \%$ less than ICBA-Q3. The grain yields of ICBA-Q3 and ICBA-Q4 were comparable at 10-15 $\mathrm{dS} \mathrm{m}^{-1}$. However, a significant reduction in grain yields was observed at higher salinity level.

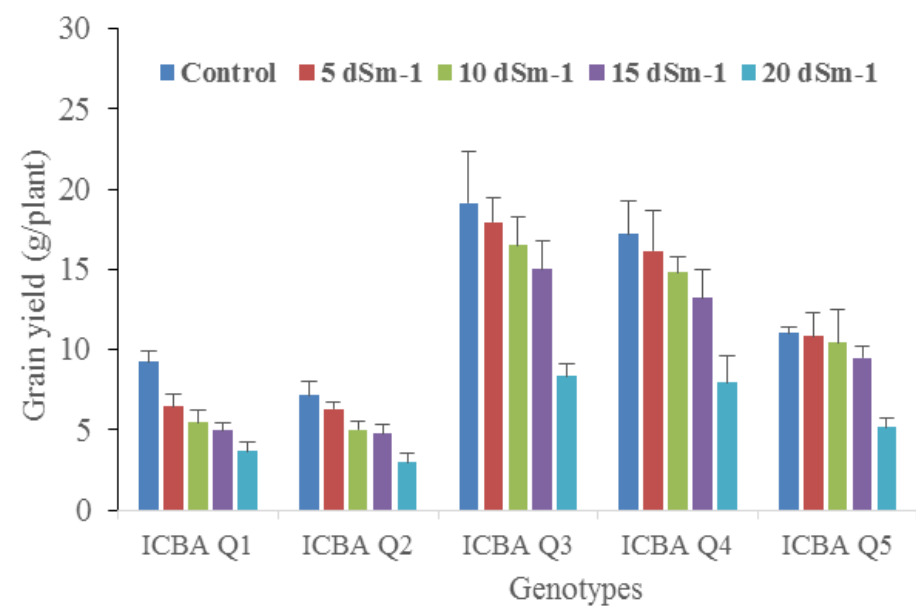

Fig. 3: Grain yield of five quinoa genotypes as affected by different salinity levels. 
Asad Sarwar Qureshi, Ashenafi Worku Daba., 2020. Differential analysis of five Quinoa (Chenopodium quinoa $W_{\text {.) }}$ genotypes under different salt stresses in a controlled environment/American-Eurasian Journal of Sustainable Agriculture. 14(1): 14-21.DOI: 10.22587/aejsa.2020.14.1.2

\section{Nutritional analysis}

Due to the distinct variation among quinoa genotypes, their responses to different salinity regimes for nutritional parameters were also different. Table 3 shows that the protein content of quinoa compares well to barley (10.5) and maize (10.2) whereas it is $30 \%$ higher than rice (7.2). Similarly, Ash content of quinoa is comparable or higher than wheat and barley (2.2), maize (1.7) and rice (3.4) [18]. The highest average protein content was found in ICBA-Q3, whereas the lowest was recorded in ICBA-Q5. The starch percentage in all genotypes is comparable and is much lower than other competitive crops such as wheat, rice and finger millet. Fe content os quinoa is also higher than the traditional crops such as wheat, rice and maize. Other nutritional parameters also showed similar trends. This makes it a healthy food for humans and can be used in cooking and baking of various products, industrial use of starch, protein, and saponin. It can also be used as a highly nutritious feed for animals $[19,20]$. This clearly shows that due to its unique nutritional balance, quinoa can be a valuable crop for marginal lands of Ethiopia and other countries of the region.

Table 3: Nutrient composition of 5 quinoa genotypes under different salinity conditions

\begin{tabular}{|c|c|c|c|c|c|c|c|c|c|}
\hline Genotypes & \begin{tabular}{|c|}
$\mathrm{EC}$ \\
$\left(\mathrm{dSm}^{-1}\right)$
\end{tabular} & $\begin{array}{c}\text { Amylose } \\
(\%)\end{array}$ & $\begin{array}{c}\text { Amylopectin } \\
(\%)\end{array}$ & $\begin{array}{l}\text { Ash } \\
(\%)\end{array}$ & $\begin{array}{c}\text { Starch } \\
(\%)\end{array}$ & $\begin{array}{c}\text { Moisture } \\
(\%)\end{array}$ & $\begin{array}{c}\mathbf{F e} \\
(\mathbf{p p m})\end{array}$ & $\begin{array}{c}\mathbf{Z n} \\
(\mathbf{p p m})\end{array}$ & $\begin{array}{l}\text { Protein } \\
(\%)\end{array}$ \\
\hline ICBA-Q1 & 0 & 20.10 & 33.93 & 3.30 & 54.06 & 10.31 & 56.32 & 77.89 & 9.02 \\
\hline ICBA-Q1 & 5 & 19.45 & 32.41 & 3.45 & 55.12 & 10.78 & 55.98 & 74.97 & 8.69 \\
\hline ICBA-Q1 & 10 & 19.72 & 34.45 & 3.31 & 54.17 & 10.21 & 56.10 & 73.29 & 9.05 \\
\hline ICBA-Q1 & 15 & 18.98 & 35.01 & 3.08 & 50.12 & 9.70 & 54.87 & 73.45 & 10.06 \\
\hline ICBA-Q1 & 20 & 18.72 & 35.21 & 2.98 & 53.42 & 9.54 & 52.31 & 69.87 & 9.88 \\
\hline Average & & 19.39 & 34.20 & 3.22 & 53.38 & 10.11 & 55.12 & 73.89 & 9.34 \\
\hline ICBA-Q2 & 0 & 19.47 & 35.48 & 3.97 & 55.18 & 9.96 & 57.01 & 76.31 & 9.04 \\
\hline ICBA-Q2 & 5 & 18.98 & 34.86 & 3.54 & 54.45 & 10.01 & 56.98 & 71.98 & 8.88 \\
\hline ICBA-Q2 & 10 & 19.82 & 34.96 & 3.12 & 54.78 & 9.81 & 55.86 & 72.34 & 9.91 \\
\hline ICBA-Q2 & 15 & 18.65 & 34.08 & 2.99 & 53.98 & 9.14 & 56.01 & 69.87 & 9.87 \\
\hline ICBA-Q2 & 20 & 17.97 & 33.94 & 2.67 & 53.21 & 9.58 & 55.23 & 69.80 & 10.02 \\
\hline Average & & 18.98 & 34.66 & 3.26 & 54.32 & 9.70 & 56.22 & 72.06 & 9.54 \\
\hline ICBA-Q3 & 0 & 20.01 & 33.90 & 3.21 & 55.23 & 14.32 & 56.21 & 72.57 & 9.71 \\
\hline ICBA-Q3 & 5 & 19.86 & 34.08 & 3.07 & 53.98 & 13.98 & 56.41 & 68.05 & 9.01 \\
\hline ICBA-Q3 & 10 & 19.74 & 34.97 & 2.96 & 54.97 & 14.38 & 55.15 & 69.08 & 9.54 \\
\hline ICBA-Q3 & 15 & 19.78 & 34.87 & 3.01 & 52.98 & 13.67 & 55.04 & 67.34 & 11.02 \\
\hline ICBA-Q3 & 20 & 18.95 & 35.07 & 2.91 & 52.34 & 10.56 & 53.75 & 64.66 & 10.68 \\
\hline Average & & 19.67 & 34.58 & 3.03 & 53.90 & 13.38 & 55.31 & 68.34 & 9.99 \\
\hline ICBA-Q4 & 0 & 19.86 & 34.00 & 3.92 & 56.03 & 10.95 & 56.31 & 69.75 & 7.93 \\
\hline ICBA-Q4 & 5 & 19.45 & 34.00 & 3.68 & 55.90 & 10.05 & 55.83 & 70.12 & 8.01 \\
\hline ICBA-Q4 & 10 & 19.96 & 33.80 & 3.43 & 53.76 & 9.01 & 55.98 & 68.58 & 7.74 \\
\hline ICBA-Q4 & 15 & 18.23 & 32.98 & 3.14 & 54.01 & 9.31 & 55.87 & 69.14 & 8.56 \\
\hline ICBA-Q4 & 20 & 18.00 & 33.01 & 2.54 & 52.69 & 9.02 & 53.41 & 68.51 & 9.87 \\
\hline Average & & 19.10 & 33.56 & 3.34 & 54.48 & 9.67 & 55.48 & 69.22 & 8.42 \\
\hline ICBA-Q5 & 0 & 19.52 & 34.98 & 4.03 & 54.56 & 9.98 & 55.76 & 69.45 & 7.06 \\
\hline ICBA-Q5 & 5 & 19.75 & 33.45 & 3.86 & 54.00 & 9.61 & 54.98 & 69.03 & 7.88 \\
\hline ICBA-Q5 & 10 & 19.97 & 33.01 & 3.50 & 52.98 & 9.00 & 55.65 & 67.03 & 7.72 \\
\hline ICBA-Q5 & 15 & 18.72 & 33.12 & 3.12 & 53.02 & 8.79 & 55.54 & 65.86 & 8.79 \\
\hline ICBA-Q5 & 20 & 17.98 & 32.98 & 3.06 & 53.23 & 8.31 & 53.91 & 64.87 & 8.49 \\
\hline Average & & 19.19 & 33.51 & 3.51 & 53.56 & 9.14 & 55.17 & 67.25 & 7.99 \\
\hline
\end{tabular}

\section{DISCUSSION}

The rising global demand for nutritious and healthy food has stressed the need to look for alternate crops especially for the marginal areas where agricultural production is low due to unfavourable climatic conditions, low soil fertility and lack of good quality irrigation water. In many countries, scientists are experimenting with quinoa production because it is rich in nutrients, tolerant to salinity and uses much less water than other crops. This study focused on assessing the feasibility of 5 quinoa genotypes for saline soil conditions of Ethiopia. The results indicate that the seed germination was negatively affected by the increasing salinity. The salinity impedes seed germination either without loss of viability at higher salinities and/or by inducing stress to seeds 
[21]. Gómez-Pando et al. [22] did a study on 15 salt-tolerant Peruvian accessions of quinoa and found that some genotypes showed a decline in germination and plant height under high saline conditions, while others did not or even register an increase.

The results indicate a reduction in dry biomass yield with increasing salinity, which might be due to lack of water availability and hydrolysis of reserved foods and their translocation to the growing shoots. Other factors responsible for lower dry biomass yield may include panicle length, chlorophyll concentrations, number of productive tillers, number of primary branches per panicle, and fertility percentage [23]. The reduction in plant growth and dry-matter yield under saline conditions has also been reported in several grain legumes, including $P$. vulgaris that can be ascribed by a decrease in cell elongation [22].

Gómez-Pando et al. [22] have also found a remarkable influence of quinoa genotypes on dry root mass per plant under saline conditions. This was probably due to the stunted growth of plants caused by high salt concentration in the nutrient medium. The higher salt stress causes a reduction in the rate of leaf surface expansion, which results in a considerable decrease in the dry weights of shoot, leaves, and roots [24]. This can be linked to the limited supply of metabolites to young growing tissues. Metabolic production usually occurs within the leaves and can be affected significantly at high salt stress conditions either due to the low water uptake or toxic effect of $\mathrm{NaCl}$ concentration [25].

Quinoa is rich in nutritional parameters needed for a portion of healthy food for humans as well as animals. It can be cooked alone as well by mixing with other cereals such as rice to develop the local taste. Quinoa is a new crop for marginal environments. However, many African countries have made significant advances in introducing this crop in local production systems. There is also evidence that extensive research trials are underway in the countries of the MENA region, including Egypt, Yemen, Jordan, Iran, Algeria and Tunisia [6]. This shows that quinoa has a great potential as a portion of food, feed and forage to diversify agricultural production systems in the salt-affected areas. Despite these nutritional qualities, some antinutritional factors (triterpenoid glycoside) are present in quinoa. Saponins, when present in the seeds, confer bitterness. Natural occurrence of saponins in quinoa grain is usually higher, but some native varieties have low saponin as well. Even though saponins can be removed by repeated washing or dehulling, this consumes additional resources on postharvest processing. Therefore, more research is needed to evaluate the feasibility of growing quinoa under different environmental conditions [26].

\section{CONCLUSIONS}

There are considerable differences on various plant growth parameters with the increasing salinity on five quinoa genotypes. Results revealed that nearly all parameters measured decreased with increasing levels of salinity stress. The performance of ICBA-Q3 was superior under low to moderate salinity conditions, whereas ICBA-Q4 and ICBA-Q5 showed more consistent dray matter and grain yields under higher salinity conditions. The nutritional parameters of all genotypes are less affected by increasing salinity levels. However, further optimization of these genotypes is recommended to enhance their productivity under local conditions.

\section{ACKNOWLEDGEMENTS}

The authors are thankful to the International Fund for Agriculture Development (IFAD) to provide financial support for this research work. We are also thankful to the Ministry of Agriculture and the staff of the Werer research centre of the Ethiopian Institute of Agriculture (EIAR) for their support in implementing these trials.

\section{REFERENCES}

[1] Ashenafi, W., and B. Bobe, 2016. Studies on soil physical properties of salt-affected soil in Amibara area, Central Rift Valley of Ethiopia. Inter. J. Agric. Sci. Nat. Resour. 3(2): 8-17.

[2] Frew, A., A. Tena, and A. Fentaw, 2015. Appraisal and mapping of soil salinity problems in Amibara area of Middle Awash Basin Ethiopia. International Journal of Innovation and Scientific Research, 13(1): 298-314.

[3] Birhane, H. 2017. Salinity status of soils of irrigated lands, waterlogged areas and irrigation water quality at Raya Alamata District, Ethiopia. MSc. Thesis, Haramaya University, Haramaya, Ethiopia.

[4] Ruiz, K., S. Biondi, R. Oses, I. Acuña-Rodríguez, F. Antognoni, E. Martinez-Mosqueira, A. Coulibaly, A. Canahua-Murillo, M. Pinto, A. Zurita-Silva, D. Bazile, S.E. Jacobsen, and M. Molina-Montenegro, 
Asad Sarwar Qureshi, Ashenafi Worku Daba., 2020. Differential analysis of five Quinoa (Chenopodium quinoa $W$.) genotypes under different salt stresses in a controlled environment/American-Eurasian Journal of Sustainable Agriculture. 14(1): 14-21.DOI: 10.22587/aejsa.2020.14.1.2

2014. Quinoa biodiversity and sustainability for food security under climate change. A review. Agron Sustain Dev., 34: 349-359.

[5] Bazile, D., S.E. Jacobsen, and A. Verniau, 2016a. The Global Expansion of Quinoa: Trends and Limits. Frontiers in Plant Science 7. https://doi.org/10.3389/fpls.2016.00622.

[6] Choukr-Allah, R., N.K. Rao, A. Hirich, M. Shahid, A. Alshankiti, K. Toderich, S. Gill, and K.U.R. Butt, 2016. Quinoa for Marginal Environments: Toward Future Food and Nutritional Security in MENA and Central Asia Regions. Frontiers in Plant Science 7. https://doi.org/10.3389/fpls.2016.00346.

[7] Jacobsen, S.E., 2017. The scope for adaptation of quinoa in Northern Latitudes of Europe. Journal of Agronomy and Crop Science, 203: 603-613. https://doi.org/10.1111/jac.12228.

[8] Shabala, S., Y. Hariadi, and S.E. Jacobsen, 2013. Genotypic difference in salinity tolerance in quinoa is determined by differential control of xylem Na+ loading and stomatal density. J. Plant Physio. 170: 906-914.

[9] Vega-Gálvez, A., M. Miranda, J. Vergara, E. Uribe, L. Puente, and E.A. Martínez, 2010. Nutrition facts and functional potential of quinoa (Chenopodium quinoa willd.), an ancient Andean grain: a review. Journal of the Science of Food and Agriculture, 90: 2541-2547. https://doi.org/10.1002/jsfa.4158.

[10] Scanlin, L., and K.A. Lewis, 2017. Quinoa as a Sustainable Protein Source, in: Sustainable Protein Sources, 223-238. https://doi.org/10.1016/B978-0-12-802778-3.00014-7.

[11] Wondimagegne, C., and Mnalku, A. 2012. Selected physical and chemical characteristics of soils of the Middle Awash irrigated farm. Ethiopian J. of Agriculture Science, 22: 127-142.

[12] Ashraf, M., and M.R. Foolad, 2005. Pre-sowing seed treatment-a shotgun approach to improve germination growth and crop yield under saline and none-saline conditions. Advan. Agron., 88: 223-271.

[13] Ellis, R.A., and E.H. Roberts, 1981.The quantification of ageing and survival in orthodox seeds. Seed Sci. Technol, 9: 373-409.

[14] Van Soest, P.J., J.B. Robertson, and B.A. Lewis, 1991. Methods for dietary fiber, neutral detergent fiber, and non-starch polysaccharides in relation to animal nutrition. J. Dairy Sci., 74: 3583-3597.

[15] Gomez, A., and H. Gomez, 1984. Statistical analysis for agricultural research. John Willy and Sons Inc., 120-155.

[16] Jacobsen, S.E., A. Mujica, C.R. Jensen, 2003. The resistance of quinoa (Chenopodium quinoa W.) to adverse abiotic factors. Food Reviews International, 19(1-2): 99-109.

[17] Al-Dakheel, A.J. Hussain, M.I. and Abdul Rahman, A.Q. 2015. Impact of irrigation water salinity on agronomical and quality attributes of Cenchrus ciliaris L. accessions. Agric. Wat. Manage. 159:148154. www.elsevier.com/locate/agwat.

[18] Wright, K.H., O.A. Pike, D.J. Fairbanks, C.S. Huber, 2002. Composition of Atriplex hortensis, Sweet and Bitter Chenopodium quinoa Seeds. Journal of Food Science, 67: 1383-1385. https://doi.org/10.1111/j.1365-2621.2002.tb10294.x

[19] Repo-Carrasco, R., C. Espinoza, S.E. Jacobsen, 2003. Nutritional Value and Use of the Andean Crops Quinoa (Chenopodium quinoa) and Kañiwa ( Chenopodium pallidicaule ). Food Reviews International, 19: 179-189. https://doi.org/10.1081/FRI-120018884.

[20] Jellen, E.N., P.J. Maughana, F. Fuentes, and B.A. Kolano, 2015. Botany, Phylogeny and Evolution. Chapter 1.1. In FAO \& CIRAD. In State of the Art Report of Quinoa in the World in 2013 Rome. 12-23.

[21] Breusegem, F., and J.F. Van Dat, 2006. Reactive oxygen species in plant cell death. Plant Physiology, 41: 384-390.

[22] Gómez-Pando, L.R., R. Álvarez-Castro, and B. Eguiluz-de la, 2010. A. Effect of Salt Stress on Peruvian Germplasm of Chenopodium quinoa Willd. A Promising Crop. Journal of Agronomy and Crop Science, 196: 391-396.

[23] Ali, Y. Z., Aslam, M.Y. Ashraf, and G.R. Tahir, 2004. Effect of salinity on chlorophyll concentration, leaf area, yield and yield components of rice genotypes grown under saline environment. International Journal of Environmental Science \& Technology, (3): 221-225.

[24] Kandil, A.A., A.E. Sharif, W.A.E. Abido, and M.M. İbrahim, 2012. Effect of salinity on seed germination and seedling characters of some forage sorghum genotypes. International Journal of Agriculture Sciences, 4 (7): 306-311.

[25] Hassen, A., M. Souguir, and C. Hannachi, 2014. Effect of Salt Stress (NaCl) on Germination and Early Seedling Parameters of Three Pepper Genotypes (Capsicum annuum L.). Journal of Stress Physiology and Biochemistry, 10(1): 15-25.

[26] Rao, N.K., and M. Shahid, 2012. Quinoa: A promising New Crop for Arabian Peniunsula. AmericanEurasian Journal of Agricultural and Environmental Sciences 12: 1350-1355. 